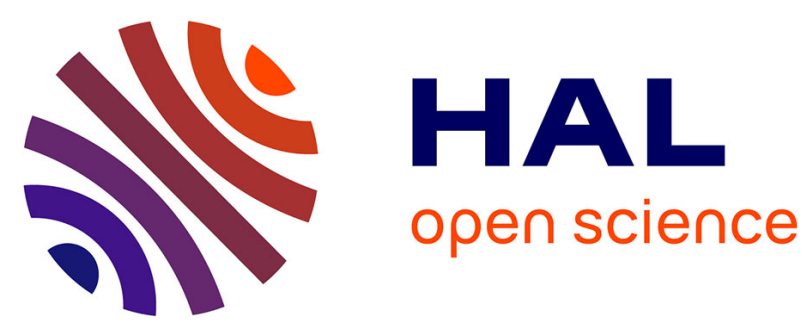

\title{
3D models related to the publication: Dental remains of cebid platyrrhines from the earliest late Miocene of Western Amazonia, Peru: macroevolutionary implications on the extant capuchin and marmoset lineages
}

Laurent Marivaux, Rodolfo Salas-Gismondi, Pierre-Olivier Antoine

\section{To cite this version:}

Laurent Marivaux, Rodolfo Salas-Gismondi, Pierre-Olivier Antoine. 3D models related to the publication: Dental remains of cebid platyrrhines from the earliest late Miocene of Western Amazonia, Peru: macroevolutionary implications on the extant capuchin and marmoset lineages. MorphoMuseum, 2017, 3 (1), 10.18563/m3.3.1.e4 . hal-01813183

\section{HAL Id: hal-01813183 \\ https://hal.umontpellier.fr/hal-01813183}

Submitted on 13 Jun 2018

HAL is a multi-disciplinary open access archive for the deposit and dissemination of scientific research documents, whether they are published or not. The documents may come from teaching and research institutions in France or abroad, or from public or private research centers.
L'archive ouverte pluridisciplinaire HAL, est destinée au dépôt et à la diffusion de documents scientifiques de niveau recherche, publiés ou non, émanant des établissements d'enseignement et de recherche français ou étrangers, des laboratoires publics ou privés. 


\title{
3D models related to the publication: Dental remains of cebid platyrrhines from the earliest late Miocene of Western Amazonia, Peru: macroevolutionary implications on the extant capuchin and marmoset lineages
}

\author{
Marivaux Laurent ${ }^{1 *}$, Salas-Gismondi Rodolfo ${ }^{2}$, Antoine Pierre-Olivier ${ }^{1}$ \\ ${ }^{1}$ Laboratoire de Paléontologie, Institut des Sciences de l'Évolution de Montpellier (ISE-M, UMR 5554, CNRS/UM/IRD/EPHE), c.c. 064, \\ Université de Montpellier, place Eugène Bataillon, 34095 Montpellier Cedex 05, France \\ ${ }^{2}$ Departamento de Paleontología de Vertebrados, Museo de Historia Natural - Universidad Nacional Mayor San Marcos (MUSM), Av. Arenales \\ 1256, Lima 11, Peru \\ *Corresponding author: laurent.marivaux@umontpellier.fr
}

\begin{abstract}
This contribution contains the 3D models of the isolated teeth attributed to stem representatives of the Cebuella and Cebus lineages (Cebuella sp. and Cebus sp.), described and figured in the following publication: Marivaux et al. (2016), Dental remains of cebid platyrrhines from the earliest late Miocene of Western Amazonia, Peru: macroevolutionary implications on the extant capuchin and marmoset lineages. American Journal of Physical Anthropology. http://dx.doi.org/10.1002/ajpa.23052
\end{abstract}

Keywords: Callitrichinae, Cebinae, Neogene, Primates, South America

Submitted:2017-08-14, published online:2017-09-13. https://doi.org/10.18563/m3.3.1.e4

\section{INTRODUCTION}

We present here the 3D digital models of five isolated teeth (Fig. 1; Table 1) documenting two distinct fossil Cebidae: Cebus sp., a medium-sized capuchin (Cebinae) and Cebuella sp., a tiny marmoset (Callitrichinae). The fossils were recently discovered in Peruvian Amazonia (Contamana, Loreto Department) from fluvial deposits (CTA-43) dating from the early late Miocene (ca. $11 \mathrm{Ma}$; i.e., Mayoan South American Land Mammal Ages [SALMA]; Antoine et al., 2016). They were recovered after wet-screening of about $800 \mathrm{~kg}$ of sediment. The material documenting Cebus sp. is a single lower $\mathrm{m} 1$ (Fig. 1A), lacking its entire buccal margin (about four-fifths of the crown are preserved). Cebuella sp. is documented by three premolars (one lower $\mathrm{p} 4$, one half $\mathrm{P} 3$ or $\mathrm{P} 4$, and one upper P2; Fig. 1B-D, respectively) and one particularly worn upper incisor (I2; Fig. 1E). Although limited, this new fossil material of platyrrhine primates is particularly critical because it testifies of the first and oldest records of the modern Cebuella and Cebus/Sapajus lineages in the lower latitudes of the Neotropics. This discovery has therefore substantial macroevolutionary implications about the origin of extant marmosets and capuchins, and it implies significant changes regarding their historical biogeography (see Marivaux et al., 2016).

\section{METHODS}

AVIZO 7.1 (Visualization Sciences Group) software was used for visualization, segmentation and 3D rendering. The teeth were prepared within a "labelfield" module of AVIZO, using

\begin{tabular}{|c|c|c|}
\hline Model IDs & Taxon & Description \\
\hline MUSM-3243 & Cebus sp. & $\begin{array}{l}\text { Left lower m1 (lingual } \\
\text { part) }\end{array}$ \\
\hline MUSM-3239 & Cebuella sp. & left lower p4 \\
\hline MUSM-3240 & Cebuella sp. & $\begin{array}{l}\text { right upper } \mathrm{P} 3 \text { or } \mathrm{P} 4 \\
\text { (buccal part) }\end{array}$ \\
\hline MUSM-3241 & Cebuella sp. & right upper P2 \\
\hline MUSM-3242 & Cebuella sp. & upper I2 \\
\hline
\end{tabular}

Table 1. List of models. All specimens come from the Museo de Historia Natural - Universidad Nacional Mayor San Marcos (MUSM), Lima, Peru.

the segmentation threshold selection tool. The 3D models are provided in .ply format, and then can be opened with a wide range of freeware.

\section{ACKNOWLEDGEMENTS}

3D data presented in this work were produced through the technical facilities of the Montpellier RIO Imaging (MRI) platform and of the LabEx CeMEB. We particularly thank R. Lebrun (ISE-M, Université de Montpellier) for his help and advices during micro-CT scan acquisitions and treatments. This work (paleontological fieldwork and laboratory post-field analyses) was financially supported by the L. S. B. Leakey Foundation. This work has also benefited from an "Investissements d'Avenir" grant managed by the Agence Nationale de la Recherche, France (CEBA, ANR-10-LABX-0025-01). 


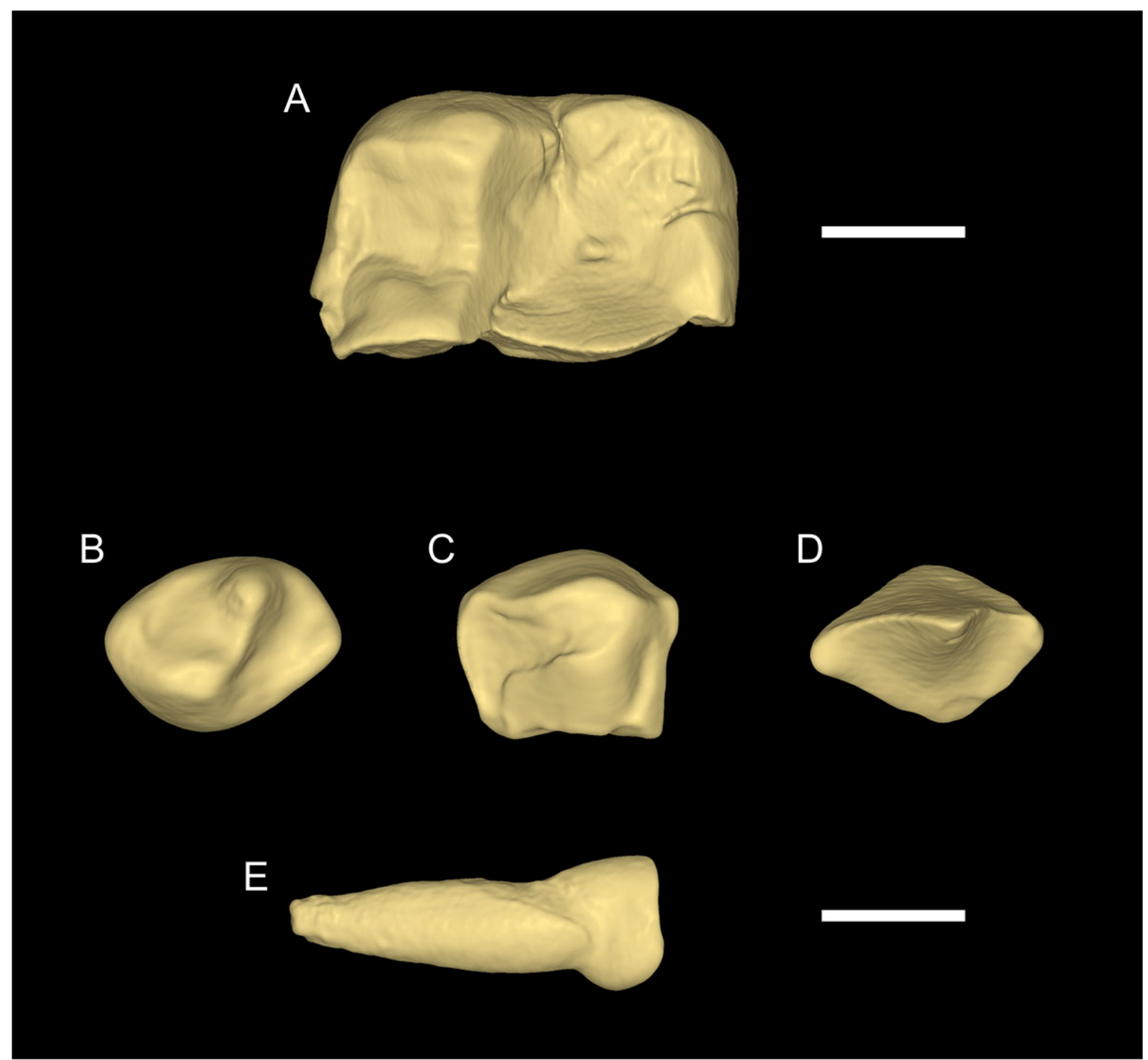

Figure 1. Fossil dental specimens of Cebus sp. and Cebuella sp. from the early late Miocene (Mayoan SALMA) of Contamana locus n 43 (CTA-43), Peruvian Amazonia. Cebus sp.: A) MUSM-3243, left m1 (lingual part). Cebuella sp. (B-E): B) MUSM-3239, left p4; C) MUSM-3240, right P3 or P4 (buccal part); D) MUSM-3241, right P2; E) MUSM-3243, upper I2. Teeth from A to D are in occlusal view, while the upper incisor is in buccal view. Scale bar $=1 \mathrm{~mm}$. 


\section{BIBLIOGRAPHY}

Antoine, P.-O., Abello, M. A., Adnet, S., Altamirano-Sierra, A. J., Baby, P., Billet, G., Boivin, M., Calderón, Y., Candela, A. M., Chabain, J., Corfu, F., Croft, D. A., Ganerød, M., Jaramillo, C., Klaus, S., Marivaux, L., Navarrete, R. E., Orliac, M. J., Parra, F., Pérez, M. E., Pujos, F., Rage, J.C., Ravel, A., Robinet, C., Roddaz, M., Tejada-Lara, J. V., Vélez-Juarbe, J., Wesselingh, F. P., Salas-Gismondi, R., 2016. A 60-million year Cenozoic history of western Amazonian ecosystems in Contamana, Eastern Peru. Gondwana Research 31, 30-59. http://dx.doi.org/10.1016/j.gr.2015.11.001

Marivaux, L., Adnet, S., Altamirano-Sierra, A. J., Pujos, F., Ramdarshan, A., Salas-Gismondi, R., Tejada-Lara, J. V., Antoine, P.-O., 2016. Dental remains of cebid platyrrhines from the earliest late Miocene of Western Amazonia, Peru: macroevolutionary implications on the extant capuchin and marmoset lineages. American Journal of Physical Anthropology 161(3), 478-493. http://dx.doi.org/10.1002/ajpa.23052 